body, lays eggs deep in the unripe fruit of the Papaya, where the maggots find an abundant and congenial food-supply. This mode of feeding, as is well known, is practised in oranges, lemons, peaches, etc., by larvæ of the notorious "Mediterranean fruit-fly" (Ceratitis capitata), which forms the subject of two papers in the Journal (vol. iii., Nos. 4 and 5), by E. A. Back and C. E. Pemberton. This fly is now a serious pest in the Hawaian Islands, though it has not yet been introduced into the United States. Attempts are being made to introduce parasitic and predaceous insects that may keep the fruit-fly in check, and one of the papers just mentioned deals with this aspect of the question. Prof. F. Silvestri made last year a special journey to West Africa in order to study the natural enemies of fruit-flies, the results of which are described in the Boll. Lab. Zool. Scuola Agric. Portici (vol. v., 1914). Here may be found diagnoses with structural figures of a number of the destructive flies and of insects which prey on them, most of the latter being small Hymenoptera.

Our own Bulletin of Entom. Research maintains the high standard of its systematic and economic papers. In vol. v., pt. 3, lately issued, Dr. W. A. Lamborn's account of agricultural pests in Southern Nigeria opens new ground, and is well illustrated with a coloured plate of Lepidoptera and several photographs of injured plants. Stanley Hirst describes mites-mostly Dermanyssus and other Gamasidæfound on rats in Egypt; while Rev. Jas. Waterston, turning for a while from Mallophaga, gives an account, with interesting structural figures, of new Chalcidoid fig-insects from Uganda. In the March number (vol. v., No. 4), just received, Mr. Waterston describes a number of parasitic Chalcidoids from tropical Africa and members of the same group from Ceylon. Among several useful papers in this number, S. A. Neave's account of the Tabanidæ of Southern Nyasaland, with descriptions of the early stages and bionomics of the species, is noteworthy. The Revieze of Applied Entomology is continued monthly, and contains excellent summaries of papers published in all parts of the world, agricultural entomology being contained in Series A, medical and veterinary subjects in Series B. In placing these publications within the reach of all students, the Imperial Bureau of Entomology abundantly justifies its existence. G. H. C.

\section{MINERAL RESOURCES OF THE PHILIPPINE ISLANDS.}

$T$ HE annual report upon the mineral resources of the Philippine Islands for the year IgI 3 has just been issued at Manila by the Division of Mines of the Government of the Philippine Islands. It gives evidence of fairly steady progress in the development of the mineral resources of these islands under American auspices. The value of the mineral production is estimated at just about $400,000 l$, an increase of about 14 per cent. above that of 19I2, but it must be remembered that these figures are made up, in accordance with the usual practice of the United States, from a number of items that are not generally included in the mineral statistics of other nations, such items as clay products, sand and gravel, and lime accounting for fully one-fourth of the total value. It is noteworthy that no coal was produced in the year under review, whereas the output for the year previous had been 2700 tons; there seems to be no good reason for this complete cessation of coal mining; it is true that one of the mines that had produced coal in Igia had been drowned out apparently through careless driving into broken ground, which seems not to have been properly tested before the drift in question was put in.

NO. 2377, VOL. 95]
Nearly one-half of the total value of the mineral output is due to the production of gold, of which 42 , OI I ounces. were obtained, both quartz mines and alluvial mines having contributed to the total. The increase of production over IgI2, when 27,582 ounces were produced, is relatively important; it is mainly due to dredging operations in the Pasacale district, where five dredges were at work, and where three additional ones were being constructed; it appears that the alluvial deposits are quite satisfactory, but that a shortage in the fuel supply, which appears hitherto to have been wood exclusively, threatens to become a serious problem in the near future.

The output of iron, in the form of castings direct from small native blast-furnaces, amounts to 227 tons, an increase of practically 50 per cent. above that in I912. These castings are almost exclusively ploughshares; they were produced in ten furnaces, each of which averaged sixty-six days in blast throughout the year; they consumed 555 tons of 60 per cent. ore and 960 tons of charcoal, the iron extracted being thus just about two-thirds of the total iron present. It is interesting to note that this primitive method of ironsmelting is still able to hold its own in the face of imports of iron more than ten times as great as the total native production.

\section{UNIVERSITY AND EDUCATIONAL INTELLIGENCE.}

BRISTOL.-The University has been concerned since its foundation with the question of residential accommodation for its students. Early in its history it received an important benefaction for the accommodation of women students in the shape of Clifton Hill House, to which the adjoining Callander House has since been added. During the past year the Imperial Hotel and a large property on Richmond Hill, Clifton, have been purchased for conversion into halls of residence for men and women training students. The University has now taken two houses for the purpose of a temporary residential college for men students. These houses are being renovated and decorated, and will be opened in good time for next term. When the arrangements are complete, the temporary college will start with accommodation for twenty-nine students.

Glasgow.-His Majesty in Council has approved the Ordinance of the University Court, empowering the University to establish a degree of bachelor of science in applied chemistry. In conjunction with the Royal Technical College, which is affiliated to the University, courses in the various branches of chemistry relating to a wide range of arts and industries will be provided. The curriculum extends above four years, and the examinations will be of an honours standard.

More than I40 students in arts, law, and pure science have volunteered for service in the munition factories during the summer vacation. Arrangements have been made by the Appointments Committee with a number of firms on the Clyde, which are prepared to give employment of the kind to students who are not eligible for active service with the forces. When the sessional examinations are completed at the beginning of June, it is expected that at least 100 more students will undertake similar work.

London.-A new edition of the University College "Pro Patria" is in course of preparation, and will be issued shortly. Past and present students, or their relatives and friends on their behalf, are invited to send full particulars of the capacity in which they are serving the country at the present time. In the case of the Army, rank and regiment should be given; in 
the case of the Navy, rank and ship. These particulars should be addressed to the Publications Secretary, University College, London (Gower Street, W.C.).

OxFORD. - The Halley Lecture will be delivered on May 20 at 8.45 p.m., in the hall of Queen's College, by Sir Frank W. Dyson, F.R.S., Astronomer Royal. The subject of the lecture, which will be illustrated with lantern-slides, is "The Measurement of the Distances of the Stars."

The Year Book Press, 3 I Museum Street, London, has been appointed by the Teachers' Registration Council as publishers of the first "Official List of Registered Teachers," which will be issued as soon as arrangements have been completed.

IN the issue of Science for May 7 it is announced that Mr. Andrew Carnegie's gifts to the Carnegie Institute and Institute of Technology-both at Pittsburgh-have now reached a total of $5,400,000 l$., his latest contribution, announced on April 29, being $540,000 l$. Of this latter amount $240,000 l$. is for new buildings, and $300,000 l$. for endowment. From the same source we learn that the campaign to raise $277,000 l$. for the Stevens Institute of Technology in Hoboken, N.J., has been concluded successfully. The entire indebtedness of the college, amounting to $77,000 l$., has been cancelled, leaving $200,000 l$. to be used for the erection of new buildings and for endowment. Gifts amounting to $14,580 l$., to be devoted to cancer research at the Harvard Medical School, have been announced. Of this sum ro,oool. is provided by the will of the late Mr. Philip C. Lockwood, of Boston. The legislature of Nebraska has granted $30,000 l$. for the erection of a teaching hospital for the University of Nebraska College of Medicine at Omaha, Nebraska.

THE Board of Education has issued a table of summer courses in England for instruction in many of the subjects of the school curriculum. The courses will be held on various dates during July, August, and September next. Nature-study appears to be one of the most popular subjects, and courses in it are being arranged at Ambleside, Bingley, Brighton, Falmouth, Great Yarmouth, Scarborough, Glastonbury, Newport, and Swanley. Geography, too, seems to be in great demand, probably in view of the growing popularity of practical methods of teaching the subject. Geographical courses are being held at Ambleside, Brighton, Cambridge, Oxford, and Sheffield. Courses in science will be held at Oxford, Wye, and Bangor, and at five centres there will be lectures on the theory of education. The official table states the authorities responsible for the courses, dates, fees, subjects of instruction, addresses for further particulars, and gives useful general remarlss. Copies can be obtained through booksellers at a cost of one penny each. The war will reduce the facilities for foreign travel, and teachers who desire to combine further study with their recreation during the long vacation should study this pamphlet.

\section{SOCIETIES AND ACADEMIES. \\ LONDON.}

Royal Society, May 13.-Sir William Crookes, president, in the chair.-Elizabeth A. Fraser and Prof. J. P. Hill: The development of the thymus, epithelial bodies and thyroid in the vulpine phalanger (Trichosurus vulpecula).-Elizabeth A. Fraser: Some observations on the development of the thymus, epithelial bodies, and thyroid in Phascolarctos, Phascolomys, and Perameles.-J. H. Brinkworth: Measurement of the specific heat of steam at atmospheric pressure and $104.5^{\circ} \mathrm{C}$., with a preface by Prof. H. L. Callendar. The No. 2377 , voL. 95] measurement of the specific heat of steam in the immediate neighbourhood of $100^{\circ} \mathrm{C}$. permits extreme steadiness in the conditions of observation, and is important as the starting point for the investigation of the variation of the specific heat with pressure and temperature, but presents special difficulties owing to the possible presence of water in suspension when the superheat is very small. The majority of determinations, such as those of Regnault ( $125^{\circ}-225^{\circ}$ C.), and Holborn and Henning ( $110^{\circ}-270^{\circ}$ C.), have been made with highly superheated steam, and throw little light on the value near $100^{\circ} \mathrm{C}$. Those of Knoblauch and Jacob, and Knoblauch and $\mathrm{H}$. Mollier, when extrapolated towards saturation, appear to indicate a very rapid increase in specific heat near the saturation point. The theory of the variation of specific heat with pressure is discussed in the preface in relation to some experiments by the Joule-Thomson method, the results of which were published in a previous communication. It is shown that the presence of only half-a-millionth of a gram-molecule of salt per gram of steam is sufficient to raise the apparent specific heat by ro per cent. at $103^{\circ} \mathrm{C}$., and that previous measurements near saturation were probably affected to a slight extent by this source of error. Special precautions were taken in the investigation to secure pure dry steam, and the conditions of experiment were varied widely, especially with regard to external heatloss. By using a silvered jacket of silica maintained at a high vacuum, the loss was reduced to about a tenth of that in previous experiments, and amounted to only two or three parts in 1000 of electric energy supplied. The final result found was $-S=2030$ joules per gram per $\mathrm{x}^{\circ} \mathrm{C}$, at $760 \mathrm{~mm}$. and $104.5^{\circ} \mathrm{C}$., which is equivalent to 0.485 mean calorie under the same conditions, and is in good agreement with Regnault's result at $175^{\circ} \mathrm{C}$., if allowance is made for the small variation deduced from the experiments by the throttling method.-C. F. Jenkin and D. R. Pye : Thermal properties of carbonic acid at low temperatures.-II. This is a continuation of the paper on the same subject published in the Phil. Trans., A, vol. ccxviii., p. 67. It contains a description of (I) a series of measurements of the total heat of $\mathrm{CO}_{2}$ gas from which the specific heats are deduced; (2) a few remeasurements of the total heat of liquid $\mathrm{CO}_{2}$; and (3) a series of throttling experiments on $\mathrm{CO}_{2}$ gas. By means of the first series the $\theta \phi$ chart, part of which was drawn in the former paper, is extended over the superheated gas area; its accuracy is then checked by means of the throttling experiments. Graphic methods are described for plotting the results of throttling experiments and thereby checking the specific heats of the gas and position of the gas-limit curve. Finally, an $\mathrm{I} \phi$ chart is constructed for $\mathrm{CO}_{2}$ based on the measurements described in both papers. To assist in the construction of this chart, a series of theorems connecting the total heat I with the other variables $p, v, \theta$, and $\phi$ are worked out, and their use in checking the accuracy of I $\phi$ charts for any substances is explained. The authors hope that the new I $\phi$ for $\mathrm{CO}_{2}$ chart, which extends and corrects Mollier's, may be of some technical value in the refrigeration industry.

Physical Society, April 23.-Dr. A. Russell, vicepresident, in the chair.-Prof. W. B. Morton and Miss Mary Darragh : The theories of Voigt and Everett regarding the origin of combination tones. Voigt connects the existence of difference and summation tones with the fact that the stationary points of the compound vibration-curve, when the primary tones have equal energies, can be grouped in a certain way on sine curves, which recur in the periods of these combination tones. As against this view it is urged (I) that the same points can equally well be grouped on a 